\title{
MAKNA SOSIAL HUKUM DALAM AKSI DAN INTERAKSI PENGELOLAAN DOSEN PERGURUAN TINGGI SWASTA
}

\author{
Oleh: Nurbaedah
}

\begin{abstract}
Abstrak
Masalah interaksi dan tindakan hukum sosial adalah upaya mencari makna sosial dari berbagai macam norma hukum kepada manajemen dosen PTS, TNlPOLRI, yang terbentuk dalam interaksi dan tindakan sosial. Interaksi ini dapat dilihat dari pola pikir dan perilaku yang berarti interaksi berdasarkan pemikiran berpola hukum, karena makna hukuman sosial diantaranya adalah berbagai macam norma hukum yang terjadi dalam pengelolaan bentuk dosen ketika norma hukum yang mempengaruhi perilaku pimpinan PTS sebagai dosen dan penyelenggara. sebagai aktor yang dikelola menggunakan hukum untuk mencapai tujuan. Hal ini yang terwujud dalam interaksi dan tindakan yang dilakukan oleh instansi, TNl-POLRI (melalui studi lapangan) di PTS, TNl-POLRI Jawa Timur merupakan fokus kajian pada penelitian ini.
\end{abstract}

Kata kunci: aksi, interaksi, makna sosial

\begin{abstract}
Problem of social punish interaction and action is effort find meaning of social from is multi various of norm punish to management of lecturer of PTS, TNl-POLRI, which is formed in interaction and action of social. This interaction can be seen from patterned thinking and behavior mean interaction pursuant to law patterned thinking, because meaning of social punish among is multi various of norm punish that happened in management of form lecturer when norm punish that influence head behavior of PTS as lecturer and organizer as managed actor use law to reach target. This matter which formed in interaction and action carried out by institution, TNl-POLRI (pass] field study at PTS, TNl-POLRI in East Java represent study focus at this research.
\end{abstract}

Key words: action, interaction, social meaning

\section{A. PENDAhULUAN}

Tujuan kemerdekaan Republik Indonesia adalah memajukan kesejahteraan umum, mencerdaskan kehidupan bangsa, dan ikut melaksanakan ketertiban dunia yang berdasarkan kemerdekaan, perdamaian abadi dan keadilan sosial (Pembukaan Undang-undang Dasar 1945). Selanjutnya dalam Pasal 31 Undangundang Dasar 1945 ditentukan bahwa: 
1. Tiap-tiap warga Negara berhak mendapatkan pengajaran dan

2. Pemerintah mengusahakan dan menyelenggarakan satu sistem pengajaran yang diatur dalam undang-undang

Dengan demikian amanat yang dicita-citakan itu mengisyaratkan bahwa lahirnya perguruan tinggi merupakan suatu keharusan. Untuk mereliasikan amanat Pasal 31 UUD 1945 tersebut di atas, maka diperlukan perangkat kebijaksanaan, yaitu acuan yang digunakan untuk mencapai keinginan (cita-cita) itu. Acuan tersebut adalah Undang-undang Nomor 2 Tahun 1989 tentang Sistem Pendidikan Nasional, yang menegaskan bahwa "pendidikan merupakan usaha sadar untuk menyiapkan peserta didik melalui upaya bimbingan, pengajaran dan atau pelatihan untuk kehidupan di masa yang akan datang, dengan tetap berakar pada kebudayaan bangsa Indonesia berdasarkan Pancasila dan Undang-undang Dasar 1945.”

Terdapat rumusan suatu kebijaksanaan tentang pendidikan nasional, yang bertujuan untuk meningkatkan kualitas manusia Indonesia, yaitu manusia yang beriman dan bertaqwa, berbudi pekerti luhur, berkepribadian mandiri, maju, tangguh, cerdas, kreatif, trampil, berdisplin, beretos kerja, professional; bertanggungjawab dan produktif.

Khusus mengenai pendidikan tinggi, maka sebagai kebijaksanaan pembangunan lima tahun, biaya pendidikan tinggi terus dibina dan dikembangkan untuk menyiapkan peseta didik menjadi anggota masyarakat yang memiliki kemampuan akademik dan atau professional, serta kemampuan kepemimpinan, yang tanggap terhadap kebutuhan pembangunan serta pengembangan pengetahuan dan teknologi, berjiwa penuh pengabdian dan memiliki rasa tanggung jawab yang besar terhadap masa depan bangsa dan negara.

Dalam Pasal 47 Undang-undang Nomor 2 Tahun 1989 disebutkan tentang peran serta masyarakat dalam penyelenggaraan pendidikan yakni "masyarakat sebagai mitra pemerintah berkesempatan seluas-luasnya dalam menyelenggarakan pendidikan nasional". Peraturan pemerintah Nomor 60 tahun 1999 tentang Pendidikan Tinggi menentukan, bahwa "pendidikan tinggi dapat diselenggarakan oleh satuan pendidikan yang diadakan oleh pemerintah masyarakat". Dari amanat Negara seperti yang digariskan dalam Pembukaan Undang- undang Dasar 1945, maupun dari tugas pemerintah untuk menyelenggarakan sistem pendidikan nasional, serta tujuan pendidikan nasional, maka jelas bahwa penyelenggaraan system pendidikan itu dimaksudkan untuk meningkatkan kualitas sumber daya manusia Indonesia, yang diperlukan untuk kepentingan pembangunan bangsa dan Negara, sekarang maupun di masa yang akan datang.

Khusus untuk pendidikan tinggi, kebijaksanaan yang akan ditempuh selain peningkatan kualitas sumber daya manusia yang menguasai ilmu pengetahuan dan teknologi, beriman dan bertaqwa, serta mempunyai kepemimpinan yang tangguh untuk pembangunan. Di samping itu, hendaknya juga dapat mengembangkan ilmu pengetahuan dan teknologi itu sendiri melalui kegiatan penelitian dan pembangunan. Oleh karena itu, penyelenggaraan perguruan tinggi, baik oleh pemerintah maupun oleh swasta memerlukan sistem yang sungguh-sungguh terpadu dan berkesinambungan, untuk memenuhi tuntutan pembangunan di masa 
mendatang.

Kondisi Perguruan Tinggi, baik negeri maupun swasta di Indonesia secara kuantitatif maupun kualitatif belum memadai. Hal ini berarti kalau dilihat dari jumlah mahasiwa maupun jumlah lulusannya belum dapat memenuhi kebutuhan pembangunan di segala bidang dan aspek kehidupan masyarakat, bangsa dan negara sekarang ini, apalagi di masa yang akan datang. Pada awal pembangunan jangka panjang tahap II, angka partisipasi mahasiswa hanya 2,4 juta atau $11 \%$ dari jumlah penduduk yang berusia antara 19 sampai 24 tahun di Indonesia yang kurang lebih ada 21 juta jiwa. Sebagai perbandingan di Philipina lebih kurang $30 \%$, Thailand lebih kurang 28\%, Malaysia lebih kurang 13\%, Korea Selatan lebih kurang 38\%, Jepang lebih kurang 53\% dan Amerika Serikat lebih kurang $68 \%$.

Mengenai kualitas perguruan tinggi swasta, dapat dilihat dari status dan program studi di perguruan tinggi tersebut. Dari jumlah PTS 1264 dengan mengelola 5515 program studi, hanya 996 program studi atau $22 \%$ berstatus diakui, dan 333 program studi atau $60 \%$ berstatus terdaftar (Dokumen Dirjendikti 1998). Melihat keadaan seperti di atas, maka pembangunan di bidang pendidikan harus dikembangkan dengan memperhatikan dan menjaga kualitas perguruan tinggi, dengan tetap mengacu pada tujuan pendidikan di Indonesia sebagaimana diatur dalam Pasal 2 Peraturan Pemerintah Nomor 60 Tahun 1999.

1. Tujuan Pendidikan Tinggi adalah

a. Menyiapkan peserta didik menjadi anggota masyarakat yang memiliki kemampuan akademik dan atau professional, yang dapat menerapkan, mengembangkan danatau memperkaya hasanah ilmu pengetahuan, teknologi dan atau kesenian

b. Mengembangkan dan menyebarluaskan ilmu pengetahuan, teknologi dan atau kesenian, serta mengupayakan penggunaannya untuk meningkatkan taraf kehidupan masyarakat dan memperkaya kebudayaan nasional

2. Penyelenggaraan kegiatan untuk mencapai tujuan sebagaimana dimaksud dalam ayat 1 , berpedoman pada:

a. Tujuan, pendidikan nasional

b. kaidah, moral, dan etika ifmu pengetahuan

c. kepentingan masyarakat, serta memperhatikan minat kemampuan dan prakarsa pribadi

Untuk mencapai tujuan pendidikan tinggi, seperti tersebut diatas, maka salah satu upaya yang harus dilakukan adalah menggunakan hukum sebagai pedoman pengelolaan perguruan tinggi. Salah satu variabel penting dalam mencapai tujuan pendidikan tinggi adalah pengelolaan terhadap dosen perguruan tinggi.

Pengelolaan dosen perguruan tinggi swasta yang diselenggarakan yayasan TNI POLRI, pada mulanya berdasarkan norma hukum yang dibuat oleh yayasan, yang mengacu pada Jukminpers dari Dephankam. Namun dalam perkembangannya pemerintah mengeluarkan peraturan perundang-undangan sebagai hukum yang mengatur pengelolaan dosen. Disamping itu untuk 
memenuhi kebutuhan interaksi didalam perguruan tinggi swasta itu sendiri, yang semakin kompleks terbentuklah aturan-aturan hukum pengelolaan dosen yang mengatur dirinya sendiri. Untuk memperlancar interaksi antara pengelola dan dosen sebagai aktor yang dikelola. Dengan demikian, terjadilah pluralisme atau adanya aneka norma hukum pengelolaan dosen pada PTS yang diselenggarakan yayasan TNl-POLRI tersebut.

Aneka norma hukum yang mengatur pengelolaan dosen, dalam kehidupan perguruan tinggi terintegrasi ke dalam perilaku dan perbuatan pengelola PTS, dalam hal ini adalah Rektor dan dosen yang dikelola. Aneka norma hukum tersebut ada yang terpadu secara harmonis, saling mengisi. Namun secara realita sebagian besar norma yang ada terjadi kontradiksi, yang berakibat timbulnya konflik dan kesenjangan hukum. Misalnya penerapan norma hukum dari yayasan TNl-POLRI menimbulkan perilaku pengelola yang tidak akademis, tidak tercipta suasana dialogis sebagai layaknya lembaga ilmiah, dan tidak ada rasa kemitraan dari pengelola. Yang terjadi adalah suasana authoriter dari pengelola dan selalu menganggap bawahan yang harus tunduk pada perintah-perintahnya.

Kesenjangan hukum adalah tentang perbedaan akan makna hukum antara apa yang dimaksud oleh pembuat hukum, para pelaksana hukum, dengan masyarakat awam yang menjadi pengguna hukum. Terjadinya kesenjangan hukum yang mengatur pengelolaan dosen, akan mempengaruhi kepatuhan dari dosen terhadap hukum, yang berkonsekuensi logis mempengaruhi keefektifan bekerjanya hukum dalam pengelolaan dosen. Kesenjangan hukum secara teoritis timbul karena keterkaitan antara hukum dengan gejala sosial lainnya seperti, politik, ekonomi, sosial dan budaya. Pandangan ini dilatar belakangi oleh pandangan bahwa hukum secara umum tidak dapat dilepaskan dari tingkah laku anggota masyarakat yang terkena aturan hukum itu, oleh karena hukum itu tidak terlaksana dengan sendirinya melainkan dilaksanakan oleh anggota masyarakat. Demikian pandangan Benda-Beckmann. F. Von, dalam bukunya Why Law Does Not behave Critical and Constructive Reflection on The Social Scientific Perspective of The Social Significance of Law.

Dari tingkah laku pengelola perguruan tinggi swasta dalam kedudukannya sebagai birokrat, dan dari tingkah laku dosen sebagai aktor pelaksana hukum akan dapat diketahui aturan hukum mana yang bermakna sosial untuk mengatur perilaku atau mengendalikan perilaku mereka. Dengan perkataan lain norma hukum mana yang menjadi pedoman bertindak dan berinteraksi dalam pengelolaan dosen. Mengenai hukum yang diterima atau dipilih atau bermakna sosiai dikemukakan sebagai berikut:

".... law can become significant only by having to do with behavior in a theoretically meaningful way .... Law becomes significant socially when human behavior is influenced by law and when people make use of law in purposive conduct" (Benda- Beckmann, 1983:90)

Penerimaan hukum oleh masyarakat juga dipengaruhi oleh apakah substansi hukum tersebut mengandung nilai-nilai moral spiritual yang layak, sehingga diyakini untuk diterima oleh agen dan aktor pelaksana hukum. Berdasarkan pandangan diatas, maka makna sosial hukum diantara aneka norma hukum yang 
terjadi dalam pengelolaan dosen, terwujud ketika norma hukum itu mempengaruhi tingkah laku pimpinan PTS sebagai pengelola dan dosen sebagai aktor yang dikelola menggunakan hukum untuk mencapai tujuannya. Upaya untuk menemukan makna aneka norma hukum bagi pengelolaan dosen PTS yang terbentuk dalam aksi dan interaksi sosial kelompok dosen PTS yang diselenggarakan oleh yayasan TNl-POLRI, melalui studi lapangan pada PTS TNlPOLRI di Jawa Timur, merupakan focus kajian penelitian dalam penelitian ini. Selanjutnya fokus kajian dalam penelitian ini:

1. Apa peran hukum yang dikeluarkan oleh yayasan TNl-POLRI yang menjadi landasan sistem pengelolaan dosen PTS?

2. Bagaimana interaksi antara norma hukum dari yayasan TNl-POLRI yang menjadi landasan pengelolaan dosen dengan hukum Negara yang menjadi landasan sistem pengelolaan dosen secara teknis dalam menunjang tugas-tugas dosen?

3. Dalam implementasinya norma hukum manakah yang berfungsi efektif, sehingga bermakna sosial pada pengelolaan dosen?

4. Bagaimana aplikasi makna sosial aneka norma hukum yang terbentuk dalam aksi dan interaksi kelompok dosen di tengah era reformasi?

Fokus masalah tersebut, didekati melalui pendekatan sosio legal, yaitu bertitik tolak dari :

1. SK Yayasan tentang pengelolaan dosen

2. SK MENKO WASPAN No. 38/KEP/MK.WASPAN/8/1999

3. SK REKTOR tentang Pengelolaan Dosen

Hukum dalam hal ini dikonsepkan secara sosiologik yaitu sebagai pelaksanaan kegiatan pengelolaan PTS dan kegiatan dosennya. Disamping itu juga menggunakan paradigma akal budi atau hati nurani, di mana nilai-nilai seperti musyawarah, keselarasan, keseimbangan dapat digunakan dalam pengelolaan dosen. Hal ini senada dengan yang di ajukan Satjipto Rahardjo dengan Doktrin Alternatifnya "bahwa untuk membangun hukum di Indonesia lebih ditekankan pada aspek moral daripada aspek peraturan perundang-undangan.

\section{B. MAKNA SOSIAL HUKUM}

Dalam mengkaji norma hukum mana yang bermakna sosial dalam pengelolaan dosen Perguruan Tinggi yang diselenggarakan Yayasan TNl-POLRI, terlebih dahulu dijelaskan pengertian makna sosial hukum. Hukum dikatakan mempunyai makna sosial, apabila tindakan atau perbuatan manusia dipengaruhi oleh hukum, dan apabila masyarakat pengguna hukum itu menggunakannya sebagai pedoman bertindak atau berbuat Selanjutnya makna sosial hukum, dapat didekati dari fungsi-fungsi dosen yang dikerjakan oleh hukum di dalam masyarakat. Dalam hal ini ada empat fungsi hukum sebagai berikut:

1. Menetapkan hubungan-hubungan antara para anggota masyarakat, dengan menunjukkan jenis-jenis tingkah laku apa yang dipekerjakan dan apa yang dilarang;

2. Menentukan pembagian kekuasaan dan memerinci siapa yang boleh secara sah 
melakukan paksaan, serta siapakah yang harus mentaatinya, dan sekaligus memilihkan sanksi-sanksi yang tepat dan efektif;

3. Menyelesaikan sengketa; dan

4. Memelihara kemampuan masyarakat untuk menyesuaikan diri dengan kondisikondisi kehidupan yang berubah dengan cara merumuskan kembali hubunganhubungan antara para anggota masyarakat

Tindakan atau perbuatan masyarakat berkaitan erat dengan interaksi sosial yang dilakukannya. Didalam interaksi sosial muncul situasi-situasi yang berpengaruh terhadap tindakan atau perbuatan warga masyarakat. Dalam situasi perubahan sosial peran hukum menjadi penting, yakni sebagai pengatur dan pengendali interaksi sosial agar terwujud ketertiban dalam masyarakat. Untuk mengidentifikasi makan sosial hukum masyarakat perguruan tinggi swasta TNlPOLRI dalam pengelolaan dosen, merupakan salah satu tugas studi hukum dan masyarakat, dilakukan dengan cara menafsirkan (interopretation) dan memahami (verstehen) seperangkat norma hukum yang berpengaruh dalam masyarakat PTS yang bersangkutan, atau hukum yang digunakan oleh warga PTS sebagai acuan bertindak dan berinteraksi.

Penafsiran dan pemahaman makna sosial hukum dalam tindakan dan interaksi pengelolaan, yaitu Rektor dan Dosen sebagai aktor antara lain dengan mengkaji langsung praktek pengalaman secara konkrit atas apa yang terjadi dalam pengelolaan dosen PTS TNl-POLRI di Jawa Timur. Untuk menemukan makna sosial hukum diantara aneka norma hukum, maka hukum itu harus dirumuskan dengan jelas. Selanjutnya menentukan metode apa yang tepat diterapkan untuk memahami makna sosial hukum itu.

Menurut Hoebel, hukum ditemukan dalam keputusan para pemegang otoritas hukum sewaktu menyelesaikan persoalan atau konflik. Dalam hal ini hukum ditemukan dari Keputusan Rektor manakala menyelesaikan kasus-kasus atau sengketa dalam pengelolaan dosen itulah yang dijadikan unit of analysis, untuk menemukan hukum mana yang berlaku di masyarakat PTS. Menurut Terhaar, disamping hukum dapat ditemukan pada keputusan-keputusan pejabat ketika menyelesaikan kasus, juga ditemukan dalam pernyataan warga masyarakat mengenai apa yang mereka kerjakan, apa yang seharusnya mereka kerjakan, atau yang tadinya ingin dikerjakan, sebagai tindakan yang menyesuaikan diri dengan seperangkat aturan atau menyimpang dari aturan itu. Dengan perkataan lain, pernyataan masyarakat di satu sisi merupakan penjelasan atau penafsiran tindakan-tindakan atau kejadian-kejadian tertentu. Di sisi lain, pernyataan masyarakat mengenai norma-norma ideal yang ia harapkan. Dengan demikian hukum dapat ditemukan dalam tindakan anusia, dalam kasus sengketa, maupun tanpa sengketa.

Adapun sebagai pendekatan teori yang digunakan dalam mengkaji makna sosial hukum sebagai berikut:

1. Untuk memahami interaksi antara warga masyarakat dengan struktur sosialnya dilakukan dengan teori strukturisasi (structuration)

2. Untuk memahami tindakan dan interaksi para pelaku sosial digunakan teori interaksionisme simbolik, guna mengungkap makna yang terkandung dibalik tindakan dan interaksi yang dilakukan. 
Sejalan dengan penggunakan teori-teori di atas, maka kajian makna sosial hukum dilakukan pada dua bidang yaitu:

1. Dibidang struktur dan perilaku penegak hukum dan

2. Dibidang kultur dan perilaku warga masyarakat yang menggunakan hukum (Widnjo Soebroto, 1985:2)

Dalam pengelolaan dosen yang termasuk penegak hukum adalah yayasan PTS dan aparatnya, Rektor dan aparatnya. Sedangkan yang termasuk pengguna hukum adalah Dosen PTS.

\section{Kesimpulan}

Dalam makalah intisari ini dapat disimpulkan sebagai berikut:

1. Fokus masalah adalah upaya menemukan makna sosial dari aneka norma hukum bagi pengelolaan dosen PTS TNI POLRI, yang terbentuk dalam aksi dan interaksi sosial kelompok dosen PTS TNl-POLRI, melalui penelitian empiris

2. Pendekatan studi dalam penelitian ini adalah sosio legal, dengan mengambil paradigma akal budi atau paradigma hati nurani

Landasan teori yang diambil dalam penelitian ini

1. Teori strukturisasi

2. Teori interaksionisme simbolik

\section{DAFTAR PUSTAKA}

Atmosudirdjo, Prayudi. Hukum Administrasi Negara. Ghalia Indonesia. Jakarta. 1990

Abdul Kadie, Muhammad. Pengantar Hukum Perusahaan Indonesia. Citra Aditya Bhakti. Bandung. 1991

Busro, Abubakar. Nilai dan Berbagai Aspeknya Dalam Hukum. Bathara. Jakarta. 1989

Bernard, Chester I. The Fuction of Executive. Harvard University Press. Cambridge Messachusette. 1978

Black, Donald, The Behavior of Law Departement of Sociology. Yale University, New Harven, Connecticut. 1976

Campbell. Enid. Legal Research Material and Methods. The Law Books Company Limited. Sydney. 1979

Child. Jhon. Organization A Guide To Problem and Practice. Harver and Rom Ltd. London. 1981

Churhill. Gregory. Petunjuk Penelusuran Literature Hukum Indonesia. Fakultas Hukum Universitas Indonesia. 1991

Donnel. Barness and Metzger. Law ForBusiness. Irwin Homewood. Illinois. 1983

Dunne. J,M. Van \& Brught. Gr. Van Der. Penyalahgunaan Keadaan. Semarang. 1988 
, Dialektika Penemuan Hukum dan Pembentukan Hukum. UNDIP. Semarang. 1971

Epstein, David G. Debtor-Creditor Law. West Publishing Company. Atlanta. 1985

Friedmann, Lawrence. M. The Legal System. Russel Saga, New York. 1975

Hart H.L.A. The Concept of Law. Oxford University Press. 1972

Himawan, Charles. Hukum Disadari Sebagai Alat Pembangunan. Prisma, No. 1. 1981 